JOURNAL OF MECHANICAL ENGINEERING, MANUFACTURES, MATERIALS AND ENERGY

\title{
Manufacture of Water Pipe From Clampshell Powder Materials
}

\author{
Abdul Rahmansyah1) *, Zulfikar2), Bobby Umroh²) \\ 1) Mechanical Engineering Dept., Institute of Teknologi Medan, Indonesia \\ 2) Mechanical Engineering Dept., University of Medan Area, Indonesia
}

* rahmansyahabdul96@gmail.com

\begin{abstract}
In general, household waste water pipelines use plastic pipes of PVC type that are not environmentally friendly and are relatively expensive. Therefore, this research will design molds and manufacture of composite pipes using raw materials of clampshell powder. The raw material used is clampshell powder with the composition of $\mathrm{MgO}$ and $\mathrm{CaO}$ compounds which is about $22.28 \%$ and $66.70 \%$. The mixture of materials used consisted of clampshell powder with a size of 40 mesh, catalyst, and unsaturated polyester resin as a matrix. The objective of this study is manufacture of water pipes made from polymer composites reinforced by clampshell powder. Composite pipe manufacturing is carried out using the casting method. Pipe molds are made of stainless steel with a diameter of $40.46 \mathrm{~mm}$ (1.6 in) and an outer diameter of 50.8 mm (2 in). This mold size follows SNI 06-0084-2002 standards. The results of the study, water pipes from polymer composite material reinforced by clampshell powder with an inner diameter size of $40.64 \mathrm{~mm}$ and varying outside diameter. This variation depends on the composition of the clampshell powder in composite materials. The greater the clampshell powder composition, the more easily the maximum pipe wall thickness can be obtained. The average wall thickness variation is $3.35 \mathrm{~mm}$. This variation is still included in the polymer water pipe requirements, which is a minimum of $2 \mathrm{~mm}$.
\end{abstract}

Keywords: Water pipe; clampshell powder; casting method; polymeric composites

How to Cite: Rahmansyah, A. Manufacture of Water Pipe From Clampshell Powder Materials, JMEMME, 2 (2): 73-77 


\section{Abdul Rahmansyah, Manufacture of Water Pipe From Clampshell Powder Materials}

\section{INTRODUCTION}

The progress of science and technology in the material industry has led to an increase in demand for composite materials. This progress has caused the use of conventional materials such as metals to be limited to meet the needs of new applications. The manufacture of aircraft, shipping, automobiles and the transportation industry are examples of industries that now require the use of materials that are lightweight, rust resistant, strong, resistant to wear and fatigue and economical.

Some research has been done in the use of natural materials. Banana powder material has been used as a filler in the manufacture of PVC pipes to increase its elastic strength(Dan-asabe, 2016), bamboo powder material is used as a raw material for plastic composite boards(Li et al., 2013), and the addition of activated carbon materials to increase the hardness of Aluminum alloys(T, 2016). In this study, the natural material studied was clampshell powder. Research with raw materials from this material is still very limited and is one of the factors of interest of researchers to conduct further research.

In this study, the type of clampshell used was the type of Anadara antiquata which is often cultivated and consumed as a source of protein. Some similar studies that have been conducted include: the use of clampshell powder as a substitute for aggregate concrete mixtures(Zuraidah, S, Hastono, \& Soemantoro, 2017), and the use of clampshell powder for toothpaste mixtures(Ahmad, 2017).

This research was carried out based on the results of previous studies with the main topic being the use of natural materials as alternative engineering materials. The road map of this study began with the manufacture of polymeric foam composite materials from oil palm empty fruit bunches (TKKS)(Zulfikar, 2010), manufactur of composite materials from areca nut fibers(Arief \& Zulfikar, 2012), making parking bumpers from TKKS material, and making water pipes from wood charcoal(Zulfikar \& Misdawati, 2018).

Thermoset resins include groups of polymers used as coatings, adhesives, and matrices in composite materials. Resins are formed through chemical reactions, where the resin with the catalyst is mixed in one medium and a hardening process (polymerization) occurs. The choice of unsaturated polyester resin as the base material is because this resin has good resistance to chemical reactions and is a good anti-corrosion coating(Koh \& Madsen, 2018). But this material when standing alone has a fragile structure, easy to crack, and low resistance to blows or pressure(Zhang, Ernst, \& Brouwer, 1997). Therefore, this material must be mixed with other ingredients as fillers to obtain the desired material characteristics(Zhang, Ernst, \& Brouwer, 1998). In this study, thermoset resin was used as a matrix of the composite material formed.

This study objective is to manufacture water pipes of polymer composite with reinforcing material of powder clampshell. The pipe produced must comply with SNI 06-0084-2002 standards, with a minimum wall thickness of $2 \mathrm{~mm}$.

\section{METHODOLOGY}

The material used in this study is clampshell, unsaturated polyester resin, 
and catalyst. The clampshell is first crushed by using a hammer mill type destroyer with a power of $20 \mathrm{hp}$ and a capacity of $100 \mathrm{~kg} /$ hour. Furthermore, the crushed clampshell is smoothed using a rod mill smoothing device with a power of $20 \mathrm{hp}$ and a capacity of $2 \mathrm{~kg} \mathrm{/} \mathrm{hour.} \mathrm{Finally,} \mathrm{the} \mathrm{resulting}$ clampshell powder will be filtered using a Mesh 40 filter (0.24 $\mathrm{mm}$ in diameter).

Equipment for manufacturing water pipes using an open cast molding device as shown in figure 1.

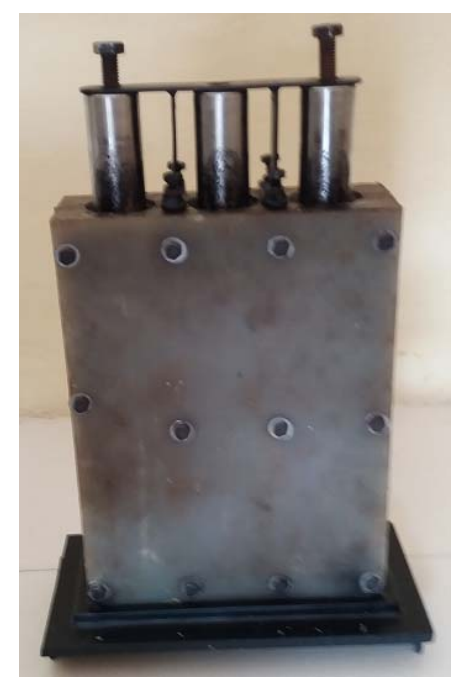

Figure 1. Water pipe manufacturing equipment

The technique of manufacturing polymer composite pipes is by casting methods in open molds. In this method, the composite material is still in the liquid phase casted into the pipe mold and stirred slowly until the liquid turns into gel form.

In this study, the composition of clampshell powder that are manufactured is $10 \%, 30 \%$ and $50 \%$. Based on observations, the composition of the powder above $50 \%$ will not produce a good product because the resin is no longer able to cover the powder.

\section{RESULT AND DICUSSION}

The process of casting raw materials into molds is done slowly and thoroughly because of the narrow mold space. The process is shown in Figure 2.

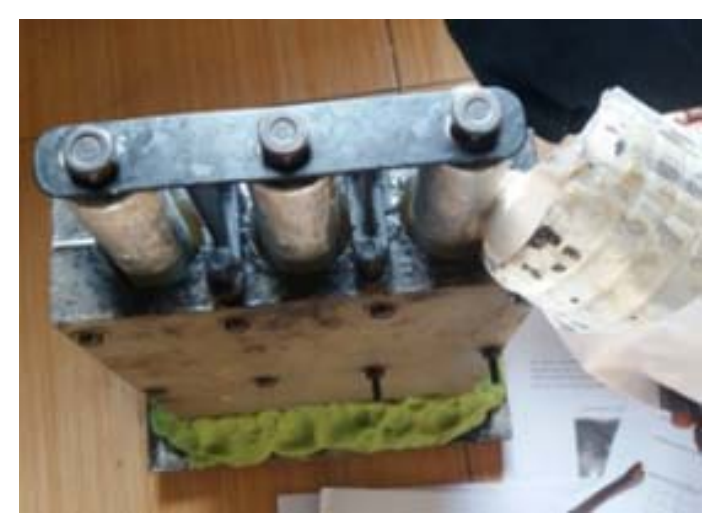

Figure 2. The process of casting raw materials into a mold

The casting process is carried out slowly and evenly so that each mold cavity is filled with composite material. The slow stirring process is given in order to remove gas bubbles trapped in the matrix. The process of dismantling the mold is done by pulling the inside mold of the composite pipe in the form of a stainless steel cylinder pipe. The result is a composite pipe that has an outer diameter of $50.8 \mathrm{~mm}$ ( 2 inches), an inner diameter of $40.64 \mathrm{~mm}$ (1.6 inches) and a length of $\pm 300 \mathrm{~mm}$ (11.8 inches).

$$
\text { The hardening process }
$$
(polymerization) will take about 30 minutes. Furthermore, the product must be disassembled before the product surface hardens. This process is carried out to avoid damage to the pipes produced during the demolition process. The pipe product produced is shown in Figure 3. 
The water pipe produced has a diameter of $25.4 \mathrm{~mm}$ and a length of 300 $\mathrm{mm}$. Meanwhile, the pipe wall thickness varies between 2.5 to $5 \mathrm{~mm}$, as shown in table 1.

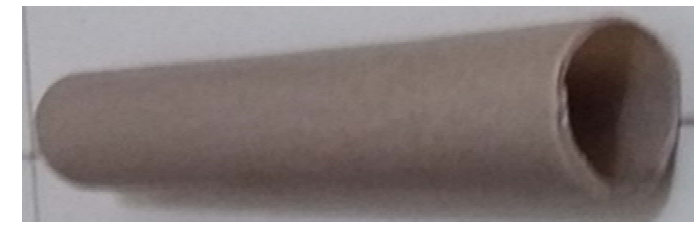

Figure 3. Water pipe from clamshell powder

Table 1. Variation in wall thickness of water pipes

\begin{tabular}{rcc}
\hline No. & $\begin{array}{c}\text { Clampshell } \\
\text { Powder (\%) }\end{array}$ & $\begin{array}{c}\text { Pipe wall } \\
\text { thickness } \\
\text { (mm) }\end{array}$ \\
\hline 1 & 10 & 2,5 \\
2 & 10 & 2,5 \\
3 & 10 & 2,8 \\
4 & 10 & 2,7 \\
5 & 30 & 3,0 \\
6 & 30 & 3,2 \\
7 & 30 & 3,0 \\
8 & 30 & 3,5 \\
9 & 50 & 4,5 \\
10 & 50 & 5,0 \\
11 & 50 & 4,0 \\
12 & 50 & 3,5 \\
\hline
\end{tabular}

Based on data from specimen manufacturing results, there are differences in the wall thickness of the pipe produced. The maximum pipe wall thickness in the mold is $5 \mathrm{~mm}$. In the hardening process, a very strong bond is formed between one molecule and the other polymer molecule. This bond causes the polymer material to give a compressive force to the inner mold. Therefore, the bond between the polymeric material and the outer mold wall becomes weak and easily separated. Thus, it will be difficult to get the maximum pipe diameter. In addition, if the demolition process is carried out when the hardening process is complete, it will be very difficult to remove the pipe with the inside mold. This phenomenon occurs in 10 and $30 \%$ clampshell powder compositions.

In the 50\% clampshell powder composition, due to the higher amount of powder than resin, the amount of powder can reduce the pressure that occurs during the hardening process. So, even though there is a compressive force in the mold of the inner pipe, the maximum diameter of the pipe can be reached and easily dismantled.

\section{CONCLUSION}

Based on the research that has been done, the manufacture of polymer composite pipes reinforced with clampshell powder using molds that have been designed and formed can produce pipe products measuring 2 inches outside with a pipe wall thickness ranging from 2.5 - 5 mm. Based on SNI 06-0084-2002 standards for water pipes from polymeric materials, the minimum thickness required is $2 \mathrm{~mm}$. Therefore, the pipes produced from the results of this study have met the requirements of the SNI standard. However, the strength of the pipe produced still needs to be tested, such as flexural, compressive and hydrostatic strength. 


\section{ACKNOWLEDGMENT}

Thank you to the Engineering Study Program, Institute Technology of Medan (ITM) for providing facility support during the research. Thanks also to the assistants of the Production Laboratory and the Mining Materials Processing Laboratory, ITM who have allowed the use of research tools. Finally, the highest gratitude to the Supervisor, Mr. Zulfikar, ST. MT., Which has provided guidance and motivation during the research.

\section{REFERENCES}

Ahmad, I. (2017). PEMANFAATAN LIMBAH CANGKANG KERANG DARAH ( Anadara granosa ) SEBAGAI BAHAN ABRASIF DALAM PASTA GIGI Utilization of Waste Shells of Blood ( Anadara granosa) as Abrasive Ingredients in Toothpaste, 6(April), 49-59.

Arief, Z., \& Zulfikar. (2012). ANALISA KEKUATAN STATIK TARIK MATERIAL KOMPOSIT POLIMER SERAT BUAH PINANG DENGAN PERLAKUAN PERENDAMAN LARUTAN $\mathrm{NaOH} 1 \mathrm{M}_{1} \%, 3(2), 224-227$.

Dan-asabe, B. (2016). Thermo-mechanical characterization of banana particulate reinforced PVC composite as piping material. Journal of King Saud University Engineering Sciences. https://doi.org/10.1016/j.jksues.2016.11.oo1

Koh, R., \& Madsen, B. (2018). Strength Failure Criteria Analysis for a Flax Fibre Reinforced Composite. Mechanics of Materials. https://doi.org/10.1016/j.mechmat.2018.05.0 05

Li, X., Lei, B., Lin, Z., Huang, L., Tan, S., \& Cai, X. (2013). The utilization of bamboo charcoal enhances wood plastic composites with excellent mechanical and thermal properties. JOURNAL OF MATERIALSEDESIGN.

https://doi.org/10.1016/j.matdes.2013.07.028

T, R. P. (2016). Effect of synthetic graphite and activated charcoal addition on the mechanical , microstructure and wear properties of $\mathrm{AZ} 81 \mathrm{Mg}$ alloys. Integrative
Medicine Research, (x x), 1-9. https://doi.org/10.1016/j.jmrt.2015.12.001

Zhang, L., Ernst, L. J., \& Brouwer, H. R. (1997). A study of nonlinear viscoelasticity of an unsaturated polyester resin . Part 1 . Uniaxial model b , , 26, 141-166.

Zhang, L., Ernst, L. J., \& Brouwer, H. R. (1998). Transverse behavior of a unidirectional composite ( glass fibre reinforced unsaturated polyester ), 27, 37-61.

Zulfikar. (2010). PEMBUATAN DAN PENYELIDIKAN PERILAKU MEKANIK MATERIAL POLYMERIC FOAM DIPERKUAT SERAT TANDAN KOSONG KELAPA SAWIT. Mekintek, 1(1), 1-9.

Zulfikar, \& Misdawati. (2018). Manufacture of mold of polymeric composite water pipe reinforced charcoal Manufacture of mold of polymeric composite water pipe reinforced charcoal. In Friendly City 4 'From Research to Implementation For Better Sustainability' (pp. 3-8). Medan: IOP Publisher. https://doi.org/10.1088/1755-1315/

Zuraidah, S., S, L. O. A., Hastono, B., \& Soemantoro. (2017). LIMBAH CANGKANG KERANG SEBAGAI SUBTITUSI AGREGAT KASAR PADA CAMPURAN BETON. Jurnal Teknik Sipil Unitomo, 1, 21-28. 